\section{Why we agreed to step into the breach}

Published at www.cmaj.ca on Mar. I6, 2006.

$\mathrm{T}$ he recent change in $C M A$ Fs editorial leadership is troubling and disappointing. John Hoey and Anne Marie Todkill can be proud of their very forward leadership for the Journal during their tenure, and the Journal, its staff, and Canadian physicians will miss their invigorating leadership. One suspects that all the events surrounding their removal will not be revealed, perhaps, for a very long time.

CMAJ, Canada's only general medical journal, is la grande dame of this country's peer-reviewed medical journals and has enjoyed international prestige for many years. Although recent events are regrettable, it is very important that we look forward to the continuation of the Journal's mission and role in providing the best in information about medicine, public health and health policy. We were asked fill the gap as Acting Editor-inChief and Editor Emeritus until the governance of the Journal has been reviewed and new editors are appointed. We will be, we suspect, reviled by some Canadian physicians and medical journal editors for choosing to step in. Our concern for the Journal, Canadian medicine, and the very competent editorial staff has persuaded us that we must step in, in spite of the hostile reactions. Both of us are temporary, and shall step down as soon as new editors are appointed. Also, we are assured by CMA and CMA Media that we will have complete editorial independence.

The crux of this interim period is the formation of a governance review committee chaired by former Chief Justice, the Rt Honourable Antonio Lamer, with Dr. John Dossetor, CMAJ ombudsman-ethicist, as vice chair. In the meantime, the CMA has agreed to an interim governance program (www.cmaj.ca/pdfs/governance .pdf) that reflects the structure and processes developed at JAMA after Editor-in-Chief George Lundberg was dismissed in I999. ${ }^{1,2}$

In addition, the Journal Oversight Committee has been reconstituted to be chaired by Dr. Peter Tugwell, Editor of the Journal of Clinical Epidemiology, with committee members, Dr. Bruce Dancik, Dr. Stanley Vollant (an elected senior CMA official), Dr. Jean Gray and Dr. Carol Herbert. Finally, some, but not all, of the associate editors have agreed to stay with us (See the companion editorial, "Why we are staying on"). We are extremely grateful for their devotion to the Journal. Our challenge as interim editors is to maintain the momentum that previous journal editors have nurtured. We shall do everything in our power to do so. We need your support and good wishes.

\section{Noni MacDonald}

Acting Editor-in-Chief

Bruce Squires

Editor Emeritus

CMAJ

\section{REFERENCES}

Rosenberg RN, Anderson ER Jr. Editorial Governance of the Journal of the American Medical Association: a report. JAMA I999;28I(23):2239-42.

2. DeAngelis CD, Maves MD. Update of the Editorial Governance Plan for JAMA [editorial]. JAMA 2004;29I(I):I09.

\section{Why we are staying on}

Published at www.cmaj.ca on Mar. I6, 2006.

$\mathrm{R}$ eaders of the Journal will be aware that the publisher of CMAJ dismissed our Editor-in-Chief and Senior Deputy Editor on Feb. 20, 2006. Subsequently, our Acting Editor, Editorial Fellow and 2 part-time Associate Editors resigned over a dispute with the CMA and CMA Holdings about the Journal's governance and editorial independence. So, from an original 9, we are now down to only 3 part-time scientific editors.

As events unfolded in late February and early March, intense communications between the editors, the CMAJ Editorial Board (a persistent and forthright voice for change) and the CMA resulted in some immediate changes. The CMA agreed to a provisional governance plan for $C M A J$ (www.cmaj.ca/pdfs/governance .pdf), modelled after that put in place at JAMA 7 years ago. ${ }^{1}$ The plan has an explicit commitment by the CMA to editorial independence for the Journal. The CMA also agreed to reconstitute membership on the Journal Oversight Committee (JOC), which is intended to mediate between CMAJ and the CMA. Further, the CMA is establishing a "blue ribbon" panel ${ }^{2}$ to review the governance plan and to consider transparent processes for hiring and firing the editor in accordance with processes at other major medical journals. Acting Editor-in-Chief (Dr. Noni MacDonald) and Editor Emeritus (Dr. Bruce Squires) have been appointed to help see the Journal through to the submission of the panel's report, which is expected by the end of May 2006. It is not yet clear to what extent the CMA will publish or implement the recommendations of the review panel.

We remaining scientific editors have decided to stay on through this period of transition for several reasons. Under the stewardship of our former editorial team, the Journal has risen to a respected status in the Canadian and international medical communities. Our readers have come to expect high quality articles. We want to continue working with authors in a timely way, building on the years of work that have expanded the Journal's profile and impact to current levels. Further, our in-house editorial and production staff require some stability, after weeks of uncertainty about the Journal's direction. Finally, we are committed to seeing the implementation of a governance plan that will ensure independence of all sections of the Journal and the restructuring of the JOC to strengthen its role in supporting this independence.

\section{Ken Flegel \\ Associate Editor \\ Erica Weir \\ Associate Editor \\ Eric Wooltorton \\ Associate Editor \\ $\stackrel{i}{\mathrm{C} C M A J}$ \\ REFERENCES}

I. Davies HT, Rennie D. Independence, governance and trust. Redefining the relationship between JAMA and the AMA. JAMA I999;281:2344-6.

2. CMA Announces Steps to Move Journal Forward. Available: www.cma.ca/index .cfm/ci_id/47352/la_id/r.htm (accessed 2006 Mar I6). 